ISSN 2414-1143

Научный альманах стран Причерноморья. 2019. Том 20. № 4

DOI 10.23947/2414-1143-2019-20-4-55-63

UDC 929

\title{
E.V. BONDAREVSKAYA (01.01.1931 - 28.05.2017): EXPERIMENTS OF RECONSTRUCTION OF BIOGRAPHY
}

\author{
(C) Alexander G. Bermus \\ Southern Federal University, Rostov-On-Don, Russian Federation \\ bermous@sfedu.ru
}

This article is one of the first experiments in reconstructing of the scientific biography of one of the most famous figures in Russian pedagogical science, doctor of pedagogical sciences, professor, academician of the Russian Academy of Education, honored teacher of the Russian Federation Evgenia Bondarevskaya. The main stages of her biography are comprehended: from birth (1931) till the beginning of work in the Rostov State Pedagogical Institute (1958), then the period of active professional growth until 1991, the period of the highest professional recognition (1991-2011) and the period of late methodological research and completion of a professional career (2011-2017). The most characteristic for the period of professional growth of E.V. Bondarevskaya was the idea of moral education of a person, overcoming the contradictions between the unity of requirements for students within the school and the individual ways of their personal development, the development of the teacher's pedagogical culture as the leading subject organizing the educational process. In the future, these ideas are transformed into the concepts of student-centered education and the upbringing of a person's culture, morality and harmoniously developed personality. A separate direction of the scientific work of E.V. Bondarevskaya in recent years has been the development of a "humanitarian methodology" - a system of scientific and philosophical ideas about education and a person's place in it, which allows for meaningful design and reflection of educational practices in a changing social and cultural reality, successfully pairing individual processes of personal growth and global historical transformations. At the end of the article, perspective lines of development of the main ideas of her scientific work are considered. Thus, the ideas of a personal approach and personality-oriented pedagogy are transformed over time into the philosophical and cultural anthropology of childhood and the preparation of teachers for the development and implementation of varied cultural and anthropological practices; the ideas of educational complexes (clusters) will lead to the deployment of network projects for the profiling of general education and the modernization of pedagogical practices, the formation of unified educational environments and support projects for young teachers. Finally, the project of the universalization of teacher education will be associated with the development and implementation of modern corporate standards in assessing professional achievements, changing the content and structure of educational programs in the direction of increasing their competitiveness and combining scientific and educational components, as well as increasing the importance of international research and projects.

Key word: heritage of E.V. Bondarevskaya, humanitarian methodology, personality-oriented education, regional educational cluster, university-type pedagogical education.

\section{[А.Г. Бермус Е.В. Бондаревская (01.01.1931 - 28.05.2017): опыт реконструкции биографии]}

Настоящая статья представляет собой один из первых опытов реконструкции научной биографии одного из наиболее известных деятелей российской педагогической науки, доктора педагогических наук, профессора, академика Российской академии образования, заслуженного учителя Российской Федерации Евгении Васильевны Бондаревской. Осмысливаются основные этапы ее биографии: от рождения (1931) и до поступления на работу в Ростовский государственный педагогический институт (1958), затем - период активного профессионального роста до 1991 года. Период наивысшего профрессионального признания (1991 - 2011) и этап активных методологических исследований (2011 2017). Наиболее характерными для периода профессионального роста Е.В. Бондаревской стали идеи нравственного воспитания личности, преодоления противоречий между единством требований к учащимся в рамках школы и индивидуальностью путей их личностного развития, развития педагогической культуры учителя, как ведущего субъекта, организующего образовательный процесс. В дальнейшем эти идеи трансформируются в концепции личностно-ориентированного образования учащихся и воспитания человека культуры, нравственности и гармонически развитой личности. Отдельным направлением научного творчества Е.В. Бондаревской была разработка «гуманитарной методологии» - системы научно-философских представлений об образовании и месте человека в нем. Это позволяло осуществлять осмысленное проектирование и рефлексию образовательных практик в условиях изменяющейся социальной и культурной действительности, успешно координировать индивидуальные процессы личностного роста и глобальные исторические трансформации. В нашем исследовании 
рассматриваются перспективные линии развития основных идей научного творчества Евгении Васильевны. Так, идеи личностного подхода и личностно-ориентированной педагогики трансформируются с течением времени в философскую и культурную антропологию детства и подготовку педагогов к разработке и реализации вариативных культурно-антропологических практик. Идеи образовательных комплексов (кластеров) приведут к развертыванию сетевых проектов профилизации общего образования и модернизации педагогических практик, к формированию единых воспитательных сред и проектов сопровождения молодых учителей. Проект университизации педагогического образования будет связан с разработкой и внедрением современных корпоративных стандартов в оценке профессиональных достижений, изменения содержания и структуры образовательных программ, повышения их конкурентоспособности увеличением значимости международных исследований и проектов.

Ключевые слова: наследие Е.В. Бондаревской, гуманитарная методология, личностноориентированное образование, региональный образовательный кластер, педагогическое образование университетского типа.

Alexander G. Bermus - Ph.D. (Advanced Doctorate) in Pedagogy, Professor, Head of the Chair, department of Education and Pedagogical Sciences, Southern Federal University, Rostov-on-Don, Russian Federation. Russian Federation.

Бермус Александр Григорьевич - доктор педагогических наук, профрессор, заведующий кафедрой образования и педагогических наук, Южный федеральный университет, г. Ростов-на-Дону, Российская Федерация.

The scientific, human, spiritual path of Eugenia Vasilievna Bondarevskaya cannot be understood outside the context of Soviet and Russian history of the 20th and the beginning of the 21st centuries. The main stages of her life are full of deep symbolism.

E.V. Bondarevskaya was born at the junction of 1930 and 1931, when the Soviet Union laid down the existing tradition and infrastructure of the Soviet education. It was during these years that teachers or pedagogical institutes were organized in all regional centers, the main purpose of which was mass training of pedagogicall personnel for the Soviet school. The employment history of E.V. Bondarevskaya begins in the early 1950s in Tashkent, where the young family was sent by distribution (practice of sending graduates and medical specialists to work to "lift" lagging regions of the country). This determined the formation of a special "educational" type of personality in Eugenia Vasilievna, who united the idealism of aspirations combined with uncompromising in the defence of principles.

However, the real beginning of the scientific and pedagogical career was 1958, when E.V. Bondarevskaya began to work in the Rostov Pedagogical Institute as an assistant. It is symbolic that in the same year the Law of the USSR "On Strengthening of the Connection of School with Life and on Further Development of the System of National Education in the USSR" was adopted, which enshrined many existing principles and priorities for the development of Soviet and Russian education. In particular, the preamble of the law stated that "the question of strengthening of the connection between school and life and the further development of the national education system in the country is of the utmost importance for the successful solution of the tasks of communist construction", in other words, the unity of ideological attitudes and pedagogical targeting was officially announced.

Equally important was the statement of the completion of the Cultural Revolution and the entry of the Soviet Union into the "period of the developed construction of Communist society." The pedagogical and, even more so, anthropological consequence of this general political orientation became a thesis that later acquired the status of the pedagogical principle of harmonic development of the individual: "The communist pre-education of society is inextricably connected with the education of a new person, in which spiritual wealth, moral purity and physical perfection should be harmonically combined." 
Practical implementation of these principles and ideas led to many problems and contradictions, to a large extent, scientific and pedagogical activity of E.V. Bondarevskaya was devoted to the resolution of these problems and contradictions.

First of all, the designed ("leading") style of pedagogical constructions should be noted, in the context of which the essence of any pedagogical phenomenon was determined through the future state of society, as a whole. The current and extremely recent pedagogical reality, and especially the experience of the past, were not as much the object of scientific research and understanding as the object of ideological design, which led to the increasing "baseless" and "childless" of Soviet pedagogical science: the historical and humanitarian experience of the recently established Stalin era was too traumatic and difficult to interpret in Soviet political and ideological categories.

In the same era, a key contradiction is emerging throughout the 20th and early 21st centuries. Since the 1930s, the Soviet school has relied on the content and methods of pre-revolutionary pedagogy created in the context of idealistic philosophy: the priority was the development of students ' consciousness, the learning of the most important historical and ethical ideas, the formation of morality and law-abiding. Meanwhile, the principles of the Marxist (materialist) world view declared since the beginning of the revolutionary time assumed that the only reliable basis of knowledge (and accordingly, of learning) was human work (collective activity) and individual experience based on it. In that regard, one of the key problems for domestic pedagogy had been to find out the relationship between "traditional" (idealistic, based on the directive formation of consciousness) and "modern" (materialistic, based on the production action of students) approaches. While the entire structure of the school was in line with the idealistic tradition of the organized process of "learning", idealistic principles required the implementation of an activity approach, the development of creativity and the autonomy of students.

Another problem was the growing contradiction between the state and the trends of society development, on the one hand, and school tradition, on the other. The temporary liberalization of the social atmosphere in the second half of the 1950s and in the first half of the 1960s had led to global conflicts a few years later. It had become clear that the Soviet economy, which was deprived of a rigid military-political policy of the Stalinist type, was ineffective and it was no longer able to cope with the priority tasks of socio-economic development. The universal response to these imbalances is the transition to the total ideologization of the learning process.

Under these conditions, E.V. Bondarevskaya with her students (V.M. Fyodorov, O.G. Tyrtyshnaya, L.I. Yakovleva, etc.) focused on the study of the moral education of the student, within the framework of which the circle of ideas, which later would be called "personal approach" and "paradigm of personality-oriented education" [1; 2]. Let us give some of their fundamental grounds.

First, the main source and condition of success of training and education was the personality of the student (pupil) himself, his ability, inclination and need. At the same time, the concept of "personality formation" was considered as an outdated legacy of the past, and the concept of "personality development" was presented as leading.

Secondly, the development process had been determined by the students' activity, which had transformed the scientific problems of the content of training and education into the problems of organization and self-organization of the student's creative activity, that is, ultimately, into the demands towards the teacher and the educator. Accordingly, the problem of formation and development of teacher's pedagogical culture, on which E.V. Bondarevskaya worked together with T.F. Belousova, E.N. Ovchinnikov, P.P. Pivnenko and other scientists, comes to the fore. 
Finally, thirdly, the diversity of socio-pedagogical contexts of education was reduced to a rather simple dichotomy: either external conditions could contribute to the development of the individual or slow him down. Here E.V. Bondarevskaya was guided by the ideas and approaches developed under the leadership of the academician and VicePresident of Academy of Pedagogical Sciences of the USSR Yu. K. Babansky, who considered training and education as multi-factor processes to be studied and optimized in terms of obtained results and spent resources. In this concept, E.V. Bondarevskaya was one of the first who put forward the idea of educational and scientific-pedagogical committee (educational region), which included pedagogical institute, general education and specialized schools, institutions of advanced training of teachers, and subsequently resource centers and services (psychological, logopedic, institutions of additional education, etc.). Such rich educational environment ensured the variability and effectiveness of individual educational paths of students, psychological and pedagogical support and correction of negative behavior, diversity of internal and external relations. Later these were considered as universal conditions of personality-oriented education.

Since 1977 and for more than a third of a century (until 2011) E.V. Bondarevskaya had been the permanent head of the Department of Pedagogy of the Rostov State Pedagogical Institute. At that time, against the background of the destruction of Soviet ideology, a network of innovative educational institutions (schools) was beginning to form in Rostovon-Don, testing the elements of a personal approach in education [3; 4]. E.V. Bondarevskaya was elected a corresponding member of the Russian Academy of Education, and she held the honorary position of the Deputy Chairman of the Southern Branch of Russian Academy of Education. In 1996 she was awarded the title "Honored Teacher of the Russian Federation" for her active participation in the organization of innovation activities, the management of regional innovative educational programs and projects, and the training of teachers and heads of educational institutions.

The boundary of the 20th and the 21st centuries is connected with the formation of new challenges for pedagogical science and, first of all, with the exhaustion of the traditional educational model and paradigm of pedagogical science [5; 6]. The global growth of the Internet, social networks, international contacts, the internationalization of the economy and of the social sphere led to the question of the traditional statuses and values of the teacher as the plenipotentiary representative of the national State, of the sustainable national-cultural and regional identity of the person throughout the whole live [7], and of the political and ideological unity and inclusiveness of the education system. In this regard, there were internal transformations of the concept of personal approach in education being developed by E.V. Bondarevskaya: along with the well-known domestic humanist teachers (L.N. Tolstoy, K.N. Ventzel, V.A. Sukhomlynsky) she turned to the legacy of humanistic psychotherapy (A. Maslow, Ch. Bühler, C. Rogers). The target was the formation of a "man-made civilization of the future". At the same time, the concept of "personality" was complicated and deepened: in particular, along with the ideas of subjectivity, individualization, development and self-development, the ideas about "the rise of personality to the values and meanings of culture" were updated; about the establishment of the vitality, spirituality and, ultimately, the establishment of a "culture man" capable to preserve culture and to stay in it and capable to its creative transformation.

This understanding leads to a new look at the essence of the educational process [8; 9; 10], which is now redefined through "pedagogical assistance and support," including: the study of the center events of the child's life, the pedagogical interpretation of his individual characteristics; the empathetic acceptance of the student for who he is. Joint with the student projection of the stages of his further development; adaptation of educational 
means to the child's character; involving him into pedagogical and life events; liberation for dialogue, creativity, self-development and self-building are of great importance.

The rise of organizational and pedagogical activity of E.V. Bondarevskaya is connected with 2001, when she directed international, All-Russian, inter-university and regional conferences. Among them there were annual North Caucasus psycho-pedagogical readings on the problem of "Development of personality in educational systems of the South-Russian region"; International pedagogical forum "Education of the citizen, of the person of culture and morality is the basis of social technology of modern Russia"; International Congress "Slavonic Pedagogical Gathering". The results of the research were published in authors and collective monographs, reference journals, central pedagogical publications in Russia and abroad (Ukraine, Transdniester, Kazakhstan, Bulgaria, Great Britain, China).

E.V. Bondarevskaya developed and implemented Master's Program on Higher Education; researches in the theory and methodology of pedagogy continued $[11 ; 12 ; 13 ; 14$; $15 ; 16 ; 17 ; 18 ; 19]$.

In response to the growing criticism of psycho-pedagogical sciences in the second half of the 2000s for the low demand and effectiveness of research, E.V. Bondarevskaya developed a concept of ontological approach based on concepts of essence, existence of man, of humanitarian situation and reality, of human world and human formation. This leads to the introduction of humanitarian methods of knowledge, including humanitarian expertise, humanitarian design, existential dialogues, methods of feeling, self-education and others, which allow to know the subjectivity and spirituality of man, to form the educational environment.

During her fruitful creative life in science, E.V. Bondarevskaya created and participated in the writing and editing of more than 300 scientific works, among which there are monographs: "Introduction to educational culture" (1995), "Education in search of human meanings" (1995), "Pedagogy: the personality in humanistic theories and educational systems" (in collaboration with S.V. Kulnevich) (1999), "Theory and practice of the personal focused education" (2000), "The strategy of education at the modern university" (2007), "The concept and the strategy of education of students in space of Pedagogical Institute of the Southern Federal University" (2007), "Modernization of pedagogical education in innovative space of the Federal University" (2013), etc. Even more impressive is the scale of the scientific and pedagogical school created by E.V. Bondarevskaya: she had trained about 200 candidates and more than 40 doctors of pedagogical sciences.

Important milestone in judgment of the human and professional biography of E.V. Bondarevskaya on a global historical and cultural background became: International scientific and practical conference "Mission of University Pedagogical Education in the 21st Century" and the first scientific and pedagogical readings in memory of the academician of Russian Academy of Education E.V. Bondarevskaya "Humanitarian methodology and practice of modern education" which took place in the Southern Federal University on 2628 May, 2019.

The discussion took place in the following sequence: from the reconstruction of fundamental problems of pedagogical theory and practice to the determination of the contribution of E.V. Bondarevskaya and the scientific school created by her to their solution and further to the analysis of promising lines of development of education sciences in the 21st century $[20 ; 21]$. Thus, in the logic of understanding of the contribution of E.V. Bondarevskaya to the creation and development of the theory and methodology of personality-oriented education, the following directions of scientific search were identified: 
1) Regular studies of cultural and pedagogical anthropology in terms of "values", "resources", "communicative networks", "life strategies" of children and adolescents influenced by both external (institutional) and internal (personal, spiritual) grounds.

2) Development of innovative educational projects with a significant educational component, involving not only the development of modern educational practices, but also the reflection of the current transformations of cultural and anthropological bases of education.

3) Training of pedagogical and management personnel of a new type who own not only traditional management methods, but also modern business culture (strategic, crisis and environmental management; Agile, Scrum, Kanban), socio-economic studies, etc.

The next circle of ideas of E.V. Bondarevskaya is related to the formation and development of educational regions: in the past it was about educational and scientific and pedagogical complexes (ESPC). At present, the concepts of "education cluster", "education ecosystem" and, accordingly, the formation of a teacher of a new type who is ready for effective operation in these conditions are more common. A new process of interaction between institutions of higher education providing training in pedagogical areas and general education schools is concluded in the fundamentally open nature of this interaction, the inclusion of remote actors (institutes of remote education), etc. An adequate response to these realities should be:

1) Network projects of specialized education ("specialized pedagogical and psychopedagogical class" for high school students), pedagogical and research practices of students of pedagogical profiles;

2) Projects for the creation of "Unified educational environments" focused on the development and implementation of uniform standards of social and educational activity; interaction between schools and out-of-school educational authorities, state and public organizations;

3) Young Teacher Support Program, which aims at co-driving, vocational and pedagogical support for senior students and young teachers from the moment of award of targeted or delayed employment contracts to the moment of professional adaptation at the workplace;

4) New model of advisory activity of the Department of Education and Social Sciences in the system of general education, providing creation and co-driving of specific projects and programs, search of partners and investors, formation of professional networks and communities, introduction into the system of decision-making and management of modern technologies (Agile, Scrum etc.).

Finally, the third circle of ideas of E.V. Bondarevskaya was formed in accordance with the "University of Pedagogical Education" programs, with the new challenges of education closely related to the transition to program oriented management throughout the economy; inclusion of instruments of the National Technological and Logical Initiative (EduNet, NeuroNet, Worldskills competitions), a system of competitions as ideological guidelines for the development of education; requirements for internalization and export of university education (including pedagogical education). This gives rise to the following directions of development of the Department of Education and Educational Sciences:

1. Development of concept and tools of practical-oriented assessment of quality of multilevel pedagogical education, from the level of specialized pedagogical classes and groups of students, to the system of certification of personnel of higher qualification (postgraduate school), oriented on values and strategies of Worldskills.

2. Development and implementation of applied baccalaureate educational programs with two training profiles, one of which will have a "classic" scientific and subject-matter nature, and the other will have a general professional/general educational nature (organi- 
Научный альманах стран Причерноморья. 2019. Том 20. № 4

zation of additional education of students, social and educational activities in education, ensuring the safety of social and non-activity and information security of educational institutions, etc.)

3. Creation of a new generation of master's programs, retraining and advanced training programs for management and teaching personnel in the system of general and higher education, oriented to acquisition of competences in the field of organization and effective application of information and educational environments, use of modern management technologies, organization and carrying out complex sociological and marketing research in the field of education, etc.

4. Priority development of international studies and projects in the field of pedagogical education, including through institutes of network educational programs and double diplomas, organization of academic mobility, carrying out joint research with the participation of representatives of foreign scientific and educational institutions.

Henri Barbusse, the well-known French writer, noted that education renewed civilization stably. In the scientific school of Eugenia Vasilievna Bondarevskaya there are theoretical and practical developments, considering unique possibilities of creative communication, fundamental systematized methods of emotional-shaped communication and development of personality. The main thing in her education system is to raise a useful member of society who will fit into an existing society. At the same time, the adult not only serves as a personal example for the child but also works to improve himself.

\section{Лumepamypa}

1. Бондаревская Е.В. Формирование нравственного сознания старших школьников. Ростов-на-Дону: РГПИ, 1975.

2. Бондаревская Е.В. Нравственное воспитание учащихся в условиях школьной ресрормы. Ростов- на-Дону: РГПИ, 1985.

3. Бондаревская Е.В. (в соавторстве, редактор) Введение в педагогическую культуру. Ростов- на-Дону: РГПИ, 1995.

4. Бондаревская Е.В. (в соавторстве, редактор). Образование в поисках человеческих смыслов. Ростов- на-Дону: РГПИ, 1995.

5. Бондаревская Е.В., Кульневич С.В. Педагогика: личность в гуманистических теориях и системах воспитания // Е.В. Бондаревская, С.В. Кульневич. М., Ростовна-Дону, 1999.

6. Бондаревская Е.В. Теория и практика личностно-ориентированного образования. Ростов- на-Дону: Булат, 2000.

7. Бондаревская Е.В., Пивненко П.П. Ценностно-смысловые ориентиры и стратегические направления развития сельской школы / Е.В. Бондаревская, П.П. Пивненко // Педагогика. 2002. № 5. С. 52-64.

8. Бондаревская Е.В. Развитие образования в Южном федеральном округе / Е.В. Бондаревская, В.П. Борисенков, А.А. Греков // Педагогика. 2003. № 9. С. 70-76.

9. Бондаревская Е.В. Воспитание как встреча с личностью (Избранные педагогические труды в двух томах). Т.1, 2. Ростов- на-Дону: РГПУ, 2006.

10. Бондаревская Е.В. Антикризисная направленность современного воспитания // Педагогика. Антикризисная направленность современного воспитания / Е.В. Бондаревская // Педагогика. 2007. № 3. С. 3-14.

11. Бондаревская Е.В. Проблемное поле современных образовательных технологий // Известия Южного федерального университета. Педагогические науки. 2009. № 7. C. 15-25.

12. Бондаревская E.B. Методологические проблемы становления педагогического образования университетского типа // Педагогика, 2010. № 9. С. 73 - 84 
13. Бондаревская E.B. Модернизация педагогического образования в инновационном пространстве фредерального университета // Известия Волгоградского государственного педагогического университета, серия Педагогические науки. 2010. № 7. c. 43-51.

14. Бондаревская E.B. Методологические проблемы становления педагогического образования университетского типа // Известия Южного федерального университета. Педагогические науки. 2010. № 8. С. 15-29.

15. Бондаревская E.B. Методология разработки современной теории воспитания в ростовской научной школе // Известия Южного федерального университета. 2011. № 1. C. 21-30.

16. Бондаревская E.B. Поиск путей возрождения российской духовности и нравственности в контексте интеграционного подхода // Сибирский учитель. 2011. №3(76). C. 26-32.

17. Бондаревская Е.В. Гуманитарная методология науки о воспитании / Е.В. Бондаревская // Педагогика. 2012. № 7. С. 3-13.

18. Бондаревская Е.В. Проектирование инновационного пространства педагогического образования в Федеральном университете /Е.В.Бондаревская. Педагогика. 2013. №7. С. 31 - 42.

19. Бондаревская E.В. Гуманитарная методология исследования целостного образовательного процесса в педагогическом вузе // Грани познания. 2014. №6(33). www.grani.vspu.ru

20. Бермус А.Г. Введение в гуманитарную методологию. М.: Канон +, 2007. 335 с.

21. Бермус А.Г. Модернизация образования: фрилософия, политика, культура //Монография. Москва: Канон+ РООИ «Реабилитация». 2008.

\section{References}

1. Bondarevskaya E.V. Formirovanie nravstvennogo soznaniia starshikh shkolnikov. [Formation of moral consciousness of senior schoolchildren]. Rostov-on-Don: RSPI. 1975.

2. Bondarevskaya E.V. Nravstvennoe vospitanie uchashchikhsia v usloviiakh shkolnoi re-formy. [Moral education of students in conditions of a school reform]. Rostov-onDon: RSPI. 1985.

3. Bondarevskaya E.V. (co-author, editor) Vvedenie v pedagogicheskuiu kulturu. [Introduction to pedagogical culture]. Rostov-on-Don: RSPI, 1995, 10,75 p. I.

4. Bondarevskaya E.V. (co-author, editor). Obrazovanie v poiskakh cheloveche-skikh smyslov. [Education in search of human meanings]. Rostov-on-Don: RSPI. 1995.

5. Bondarevskaya E.V., Kulnevich S.V. Pedagogika: lichnost v gumanisticheskikh teoriiakh i sistemakh vospitaniia. [Pedagogy: personality in humanistic theories and systems of education]. E.V. Bondarevskaya, S.V. Kulnevich. Moscow, Rostov-on-Don: 1999.

6. Bondarevskaya E.V. Teoriia i praktika lichnostno-orientirovannogo obrazovaniia. [Theory and practice of personality-oriented education]. Rostov-on-Don: publishing house "Bulat". 2000.

7. Bondarevskaya E.V., Pivnenko P.P. Tsennostno-smyslovye orientiry i strategicheskie napravleniia razvitiia selskoi shkoly. [Value-sense guidelines and strategic directions of rural school development]. E.V. Bondarevskaya, P.P. Pivnenko. Pedagogy. 2002. No. 5. pp. 52-64.

8. Bondarevskaya E.V. Razvitie obrazovaniia v luzhnom federal'nom okruge. [Development of education in the Southern Federal District]. E.V. Bondarevskaya, V.P. Borisenkov A.A. Grekov. Pedagogy. 2003. No. 9. pp. 70-76. 
9. Bondarevskaya E.V. Vospitanie kak vstrecha s lichnos'iu. [Education as a meeting with a person] (Selected teacher works in two volumes). V.1, 2: publishing house Rostov-on-Don: in RSPU. 2006.

10. Bondarevskaya E.V. Antikrizisnaia napravlennost sovremennogo vospitaniia. [Anticrisis orientation of modern education]. Pedagogy. Antikrizisnaia napravlennost sovremennogo vospitaniia. [Anti-crisis orientation of modern education]. E.V. Bondarevskaya. Pedagogy. 2007. No. 3. pp. 3-14.

11. Bondarevskaya E.V. Problemnoe pole sovremennykh obrazovatelnykh tekhnologii. [Problematic field of modern educational technologies]. News of the Southern Federal University. Pedagogical sciences. 2009. No. 7. pp.15-25.

12. Bondarevskaya E.V. Metodologicheskie problemy stanovleniia pedagogicheskogo obrazovaniia universitetskogo tipa. [Methodological problems of formation of pedagogical education of the university type]. Pedagogy. 2010. No. 9. pp. 73- 84

13. Bondarevskaya E.V. Modernizatsiia pedagogicheskogo obrazovaniia $v$ innovatsionnom prostranstve federalnogo universiteta. [Modernization of pedagogical education in the innovation space of the Federal University]. News of the Volgograd State Pedagogical University, series "Pedagogical Sciences". 2010. No. 7. pp. 43-51.

14. Bondarevskaya E.V. Metodologicheskie problemy stanovleniia pedagogicheskogo obrazovaniia universitetskogo tipa. [Methodological problems of formation of pedagogical education of the university type]. News of the Southern Federal University. Pedagogical sciences. 2010. No. 8, pp. 15-29.

15. Bondarevskaya E.V. Metodologiia razrabotki sovremennoi teorii vospitaniia $v$ rostovskoi nauchnoi shkole. [Methodology of development of modern theory of education in the Rostov Scientific School]. News of the Southern Federal University. 2011. No. 1. pp. 21-30.

16. Bondarevskaya E.V. Poisk putei vozrozhdeniia rossiiskoi dukhovnosti i nravstvennosti $v$ kontekste integratsionnogo podkhoda. [Search for ways to revive Russian spirituality and morality in the context of the integration approach]. Siberian teacher. 2011. No. 3 (76). pp. 26-32.

17. Bondarevskaya E.V. Gumanitarnaia metodologiia nauki o vospitanii. [Humanitarian methodology of education science]. E.V. Bondarevskaya. Pedagogy. 2012. No. 7. pp. 3-13.

18. Bondarevskaya E.V. Proektirovanie innovatsionnogo prostranstva pedagogicheskogo obrazovaniia v Federalnom universitete. [Designing the innovative space of pedagogical education at the Federal University]. E.V. Bondarevskaya. Pedagogy. 2013. No. 7. pp. 31-42.

19. Bondarevskaya E.V. Gumanitarnaia metodologiia issledovaniia tselostnogo obrazovatelnogo protsessa $v$ pedagogicheskom vuze. [Humanitarian methodology of research of holistic image process in the Pedagogical University]. Facets of Knowledge. 2014. No. 6(33). Available at: www.grani.vspu.ru

20. Bermus A.G. Vvedenie v gumanitarnuiu metodologiiu. [Introduction to humanitarian methodology]. Moscow: Canon, 2007. 335 p.

21. Bermus A.G. Modernizatsiia obrazovaniia: filosofiia, politika, kultura. [Modernization of education: philosophy, politics, culture]. Monography. Moscow: Canon ROOI "Rehabilitation". 2008. 